\title{
Relating genetic variation of ecologically important tree traits to associated organisms in full-sib aspen families
}

\author{
Frauke Kleemann • Maximilian von Fragstein • Barbara Vornam • \\ Annika Müller • Christoph Leuschner • Andrea Holzschuh • Teja Tscharntke • \\ Reiner Finkeldey • Andrea Polle
}

Received: 23 May 2010/Revised: 30 October 2010/Accepted: 25 November 2010/Published online: 24 December 2010

(C) The Author(s) 2010. This article is published with open access at Springerlink.com

\begin{abstract}
Knowledge on phenological, morphometric, and phytochemical variation of local progenies of European aspen (Populus tremula, L.) is limited. The goal of this study was to characterize variation in growth and ecologically important leaf properties in aspen full-sib families in relation to interacting organisms (mycorrhiza, endophytes, and insects) and to determine whether these interactions were affected by soil application of a systemic fungicide. In local progenies, within-family variation of neutral molecular genetic markers (nuclear microsatellites) was higher than between families. Significant variation in growth, production of phenolic defensive compounds and other phytochemical leaf traits was found between families.
\end{abstract}

Communicated by G. Brazaitis.

Electronic supplementary material The online version of this article (doi:10.1007/s10342-010-0460-6) contains supplementary material, which is available to authorized users.

F. Kleemann · A. Polle $(\bowtie)$

Forstbotanik und Baumphysiologie, Büsgen-Institut, Georg-

August Universität, Büsgenweg 2, 37077 Göttingen, Germany

e-mail: apolle@gwdg.de

M. von Fragstein · A. Holzschuh · T. Tscharntke

Agrarökologie, Department für Nutzpflanzenwissenschaften,

Georg-August Universität, Grisebachstr. 6, 37077 Göttingen, Germany

B. Vornam · R. Finkeldey

Forstgenetik und Forstpflanzenzüchtung, Büsgen-Institut, Georg-

August Universität, Büsgenweg 2, 37077 Göttingen, Germany

\section{A. Müller · C. Leuschner}

Ökologie und Ökosystemforschung Albrecht-von-Haller-Institut für Pflanzenwissenschaften, Georg-August Universität, Untere

Karspüle 2, 37073 Göttingen, Germany
Phenolic compounds showed clear negative correlation with generalist herbivores, but did not result in negative trade-off with biomass production. Differences in mycorrhizal colonization were not found among full-sib families and application of a systemic fungicide suppressed neither mycorrhizal colonization nor infestation with insects. However, a strong suppression of endophytes occurred, whose long-term consequences may require attention when fungicides are used in agroforestry plantations.

Keywords Agroforestry - Molecular marker · Nitrogen · Nutrition · Phenolic compounds · Populus

\section{Introduction}

European and American aspen (Populus tremula, P. tremuloides Michx.) are among the most widespread tree species in circumpolar boreal and temperate forest regions (Hultén and Fries 1986; Dickmann and Kuzovkina 2008). They are pioneering species with low nutrient demand that colonize disturbed and shallow soils (Dimpfelmeier 1963; Tamm 2006). In contrast to other poplar species that are typically found in alluvial, riparian, and wetland ecosystems, aspens are relatively drought tolerant and form distinct forest communities. In past European silvicultural practices, aspens have usually been removed to avoid competition in even aged, traditionally managed coniferous forests (DeChantal et al. 2009). However, it has recently been recognized that aspen create habitats for specific fauna including many endangered species and therefore provide important ecosystem services (Kouki et al. 2004). To date, aspens are increasingly valued because of their ecological functions as well as a possible resource for biomass production on marginal soils. 
Traits of ecological and economic value have mainly been studied in American aspen ( $P$. tremuloides) or in hybrids of $P$. tremuloides with $P$. tremula $(\mathrm{Li}$ and $\mathrm{Wu}$ 1997; Liesebach et al. 1999), whereas less information is available on its close relative, European aspen. American aspen show significant genetic variation in the phytochemistry of defense compounds such as phenolic glucosides and condensed tannins, whereas other foliar traits such as nitrogen content respond mainly to environment (Osier and Lindroth 2006; Donaldson and Lindroth 2007). Phenolic compounds protect against Venturia shoot blight infection (Holeski et al. 2009) and influence feeding behavior of herbivorous insects on Salicaceae (RowellRahier 1984; Donaldson and Lindroth 2007). Among herbivores, generalists such as the chrysomelid beetles Phratora vitellinae, Phratora vulgatissima, and Galerucella lineola prefer leaves with low concentrations of phenol glucosides (Kendall et al. 1996; Orians et al. 1997; Glynn et al. 2004). In contrast, specialized chrysomelid beetles, for example Chrysomela populi and Gonioctena decemnotata, prefer salicaceous species with relatively high concentrations of phenol glycosides in the leaves (Orians et al. 1997; Ikonen 2002) because their larvae sequester plant-derived allelochemicals such as salicylaldehyde for defense (Pasteels et al. 1983).

Trade-off between allocation to defense compounds and growth has been reported, at least under limiting nutrient resources (Donaldson et al. 2006). Therefore, differences in growth and biomass production among $P$. tremula progenies may have consequences for phytochemical traits, in particular for allocation of defense compounds, and for interactions with associated organisms such as mycorrhizae, endophytes, or leaf-feeding insects. Since economically and ecologically sustainable biomass production requires cultivation of trees adapted to regional climate with optimum growth and stress tolerance, we investigated variation in phenological, morphological, and ecophysiological traits in a common garden experiment with seven full-sib families generated by crossing of local $P$. tremula parent trees (Göttingen, Central Germany). It is often required to apply phytoprotective agents to prevent spreading of diseases in plantations. Therefore, we also studied the influence of a systemic fungicide on plant performance and biotic interactions. The tested hypotheses were as follows: (1) full-sib aspen families show significant variation in growth and ecophysiological leaf traits that are related to parenthood and modulate interactions with associated organisms; (2) defensive compounds and growth are negatively related, providing evidence for an energetic trade-off; (3) application of a systemic fungicide has negative effects on associated organisms such as endophytes, mycorrhiza, and leaf-feeding insects.

\section{Materials and methods}

Plant materials and experimental setup

The parent $P$. tremula trees were located close to Göttingen (Geismar, $51^{\circ} 31^{\prime} \mathrm{N}, 9^{\circ} 57^{\prime} \mathrm{E}$ ). In the year 2000, shoots with male and female flowers were transported to a greenhouse and used for controlled crossing of male trees number 1, 3, and 5 with female trees number $2,4,7,8$, and 9 , respectively, resulting in the following crossings: $\mathrm{C} 1(4 \times 5), \mathrm{C} 2$ $(9 \times 5), \quad$ C3 $(8 \times 5), \quad$ C4 $(2 \times 5), \quad$ C5 $(2 \times 3), \quad$ C6 $(9 \times 3)$, and C7 $(7 \times 1)$. Seeds were germinated on moist Vermiculite (grain size 3-8 mm, Deutsche Vermiculite Dämmstoff GmbH, Sprockhövel, Germany). Seedlings were planted in pots (Fruhsdorfer soil, type N, Fruhsdorf, Germany), cultivated outdoors, and watered as necessary. In spring 2008, 8-year-old trees were out-planted according to a randomized block design with 8 blocks (4 blocks treated monthly with 751 Amistar Opti [25 $\mu \mathrm{l}$ L-1, Syngenta, Maintal, Germany], 4 control blocks treated with water). Each block contained 24 plants, i.e., 3 trees of each of the 7 full-sib families in addition to 3 plants of a further crossing that was, however, contaminated and therefore not included in further analyses. A bed contained four blocks of alternating control and fungicide-treated blocks, which were separated by plastic barriers and surrounded by a row of additional trees to avoid edge effects. The experiment consisted of two beds. The trees were cultivated for one growth phase and watered as necessary. The mean ambient air temperature was $15^{\circ} \mathrm{C}$.

Phenological and morphometric measurements

Before bud break, diameter at the bottom (root collar) and height of the main shoot of each tree were measured. Bud break at the apex of the leader shoot was scored regularly. The Julian days were recorded until the first leaf was fully expanded (according to the scores described by UPOV 1981). The trees were harvested in the first week of September 2008. At harvest, root collar diameter, height of main shoot, number of side branches, lengths of side branches, number of leaves, fresh mass of leaves, stems, fine and coarse roots were determined. Leaf mass was determined for 5 fully expanded leaves collected at the top of the leader shoot of each tree, and their areas were measured using ImageJ (http://rsbweb.nih.gov/ij/). These data were used to convert leaf mass per tree to leaf area per tree. Aliquots of plant tissues were shock-frozen in liquid nitrogen and stored at $-80^{\circ} \mathrm{C}$ for biochemical analysis. Aliquots of roots were used for mycorrhizal assessment. Other plant tissues were dried at $60^{\circ} \mathrm{C}$ to determine dry 
mass and the relative water content [(fresh mass - dry mass) $\times 100 /$ fresh mass] .

\section{Endophyte colonization}

Two fully expanded, healthy top leaves of 20 plants per treatment of $\mathrm{C} 3$ and of 18 plants per treatment of $\mathrm{C} 4$ were harvested (21 August 2008), cut into quarters and surfacesterilized for $1 \mathrm{~min}$ in $96 \% \mathrm{EtOH}, 3 \mathrm{~min}$ in $4 \% \mathrm{NaOCl}$, and $30 \mathrm{~s}$ in $96 \% \mathrm{EtOH}$. The four leaf pieces were placed upside down in a Petri dish on antibiotics containing water agar $\left(15 \mathrm{~g} \mathrm{l}^{-1}\right.$ agar with $15 \mathrm{mg}$ tetracycline, 100 ampicillin, $50 \mathrm{mg}$ kanamycin, and $0.1 \mathrm{mg}$ streptomycin) and were incubated for 7 days at $20^{\circ} \mathrm{C}$ in darkness (Petrini 1986). Subsequently, hyphal outgrowth of leaf pieces was scored as absent or present on each leaf piece yielding a scale from $0,25,50,75$, and $100 \%$ endophyte presence, respectively, per leaf in a Petri dish.

\section{Insect sampling}

Insects were captured using a sweep net and an exhauster or were identified directly on the trees. Aphids, leaf beetle larvae, and galls were quantified visually on each tree. Counting was done four times (monthly) from May to the middle of August. We recorded three leaf beetle (Phratora vitellinae, Crepidodera aurata, and Crepidodera aurea) and one aphid species (Chaitophorus populi). The adult insects were identified in the laboratory. Due to negligible abundances, miners, galls, Homoptera, and different predators were not included in statistical analysis. Leaf beetles and their larvae and other chewing insects like Symphyta larvae and caterpillars were pooled and denominated as "sum of chewing insects," and aphids and cicada were pooled as "sum of sucking insects".

\section{Mycorrhizal colonization}

To determine colonization with ectomycorrhizal fungi, fine roots were cut into small pieces and mixed. Aliquots of the mixtures were spread under a dissecting microscope (Zeiss, Stemi 2000-C), and the presence or absence of typical ectomycorrhizal mantle structures was recorded on 100 root tips per sample. To measure colonization with arbuscular mycorrhizal fungi, root samples were placed immediately after harvest in $80 \% \mathrm{EtOH}$. The samples were subsequently stained with trypan blue in lactophenol, destained and mycorrhizae detected by the presence of hyphae, arbuscules, or vesicles in root tissue whose abundance was recorded by the gridline intersection method as reported previously (Ducic et al. 2009).
Genetic analysis

To control the crossing experiment, the DNA of the parental trees and their offspring was analysed using five nuclear-encoded microsatellite markers. Total DNA was extracted from young leaves using the DNeasyPlant Minikit (Qiagen, Hilden, Germany). The amount and the quality of the DNA were analyzed by $0.8 \%$ agarose gel electrophoresis with $1 \times$ TAE as running buffer (Sambrook et al. 1989). DNA was stained with ethidium bromide and visualized by UV illumination.

For microsatellite analysis, the primers PMS14, PMS16 (Van der Schoot et al. 2000), PTR2, PTR4 (Dayanandan et al. 1998), and PTR5 (Rahman et al. 2000) were used. The PCR was carried out as described earlier with the exception that primers were labeled with the fluorescent dyes 6-carboxyfluorescein (6-FAM) or hexachloro-fluorescein phosphoramidite (HEX). Fragments were separated on the ABI Genetic Analyser in a multiplex analysis. The microsatellite alleles were recognized using the software packages Genescan 3.7 and Genotyper 3.7 from Applied Biosystems.

Microsatellite loci were scored for the analysis of genetic parameters using the computer program GENALEX (Peakall and Smouse 2001). The analysis confirmed seven of initially eight full-sib families. Genetic variances within and between full-sib families were calculated with Molecular Analysis of Variance (MAMOVA, www.biosis.ac.uk/smart/ unix/mamova) using 99 permutations.

\section{Biochemical analysis}

The biochemical analyses were conducted as described previously (Luo et al. 2006, 2008) and are therefore recorded here only briefly. Frozen leaves were ground to a fine powder in a ball mill cooled with liquid nitrogen (Retsch, Haan, Germany). Material of three plants of a fullsib family in each block was pooled. Glucose, fructose, sucrose, and starch were extracted in $\mathrm{DMSO} / \mathrm{HCl}$, and their concentrations were determined after enzymatic conversion at a wavelength of $340 \mathrm{~nm}$ (Schopfer 1989). Soluble proteins were extracted in phosphate buffer and measured spectrophotometrically at a wavelength of $562 \mathrm{~nm}$ using the bicinchoninic acid kit (BCA assay, Uptima, Montlucon, France). Bovine serum albumin served as the standard. Soluble phenolics were extracted twice in $50 \%$ methanol and measured spectrophotometrically after incubation with Folin-Ciocalteu's phenol reagent at $765 \mathrm{~nm}$. Catechin was used for calibration. Leaf pigments were extracted in $80 \%$ acetone and measured at wavelengths of $646 \mathrm{~nm}$ (chlorophyll b), $663 \mathrm{~nm}$ (chlorophyll a), and $470 \mathrm{~nm}$ (carotenoids). Their concentrations were calculated using the 
extinction coefficients determined by Lichtenthaler and Wellenburn (1983).

\section{Element analysis}

Dry leaves were milled to a fine powder in a ball mill (Retsch, Haan, Germany). The powder was wet-ashed in $65 \% \mathrm{HNO}_{3}$ at $170^{\circ} \mathrm{C}$ for $12 \mathrm{~h}$. The filtrate was used for ICP-OES analysis of P, S, K, Ca, Mg, Mn, and Fe (Spectro Analytic Instruments, Kleve, Germany) after Heinrichs et al. (1986). For analysis of nitrogen and carbon contents, leaf powder was weighed into $5 \times 9 \mathrm{~mm}$ tin cartouches (Hekatech, Wegberg, Germany) and analysed in a CHNS-O element analyzer EA1108 (Carlo Erba Instruments, Milan, Italy). Acetanilide was used as the standard.

\section{Data analysis}

Data were tested for normality with the Shapiro-Wilk's test. If required, data were log-transformed to meet the assumption of normality of residuals. For data analysis, herbivore data of all sampling dates were pooled. Differences between parameter means were considered significant when the $P$ value of the ANOVA $F$ test was less than 0.05. Univariate or multivariate analysis of variance, principle component analysis, linear mixed-effects models, simple regression, and graphics were carried out using the software R 2.10.0 (R Development Core Team 2007). The experimental design with two beds divided into four blocks each required statistical analysis with linear mixedeffects models. We fitted linear mixed-effects models ("lme"-function in package "nlme"; Pinheiro and Bates 2000) using maximum likelihood with genotype, soluble phenolics and relative leaf water content plus their twoway interactions as fixed factors. To account for nonindependence of different plot sizes, we used the following sequence of random effects: bed, block, and genotype. To account for heteroscedasticity, we inspected the residuals for constant variance and normality and used variance functions (Pinheiro and Bates 2000). For model simplification, we performed stepwise backwards model selection using the Akaike Information Criterion (AIC) (Crawley 2007; "stepAIC"-function within the "MASS"package, Venables and Ripley 2002). The minimal adequate model was the one with the lowest AIC (Burnham and Anderson 2002). Multiple comparisons among factors having a significant effect in the minimal model were calculated using Tukey contrasts with $P$-values adjusted by single-step method ("multcomp"-package, Hsu 1996). The figures were generated with the software Origin 7.0 (Origin Lab Corp., Northampton, USA).

\section{Results}

Phenotypic and genetic differences between full-sib families of $P$. tremula

Bud break, a trait under strong genetic control, revealed distinct differences between $P$. tremula crossings (Fig. 1a). Bud break was completed 8 days earlier in $\mathrm{C} 7$ than in C6. The other full-sib families showed intermediate behavior. The full-sib families furthermore differed significantly in growth (Fig. 1b) as well as in many other morphometric parameters (for details, see Supplement 1) such as the number of side shoots $(P<0.001)$, cumulative lengths of side per tree $(P=0.048)$, relative leaf water content $(P=0.003)$, relative height growth $(P=0.002)$, stem
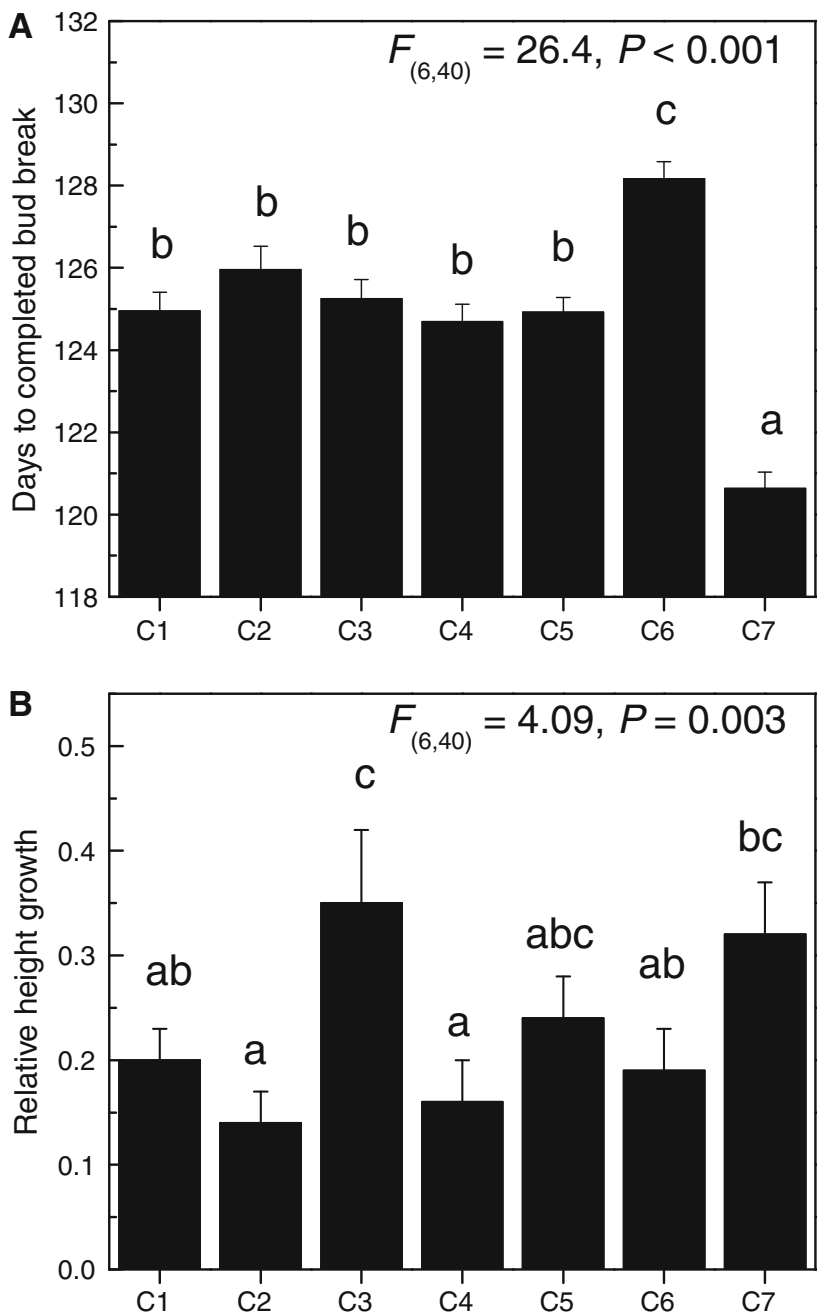

Fig. 1 Bud break (a) and relative growth rate (b) of seven full-sib families of aspen ( $P$. tremula). a Bud break was measured as Julian days to the first fully expanded leaf on the leader shoot. b Relative growth rate was determined as annual increment in shoot height/shoot height before bud break. Data indicate means ( $n=24$ to $28, \pm \mathrm{SE}$ ). Different lower-case letters indicate significant pairwise differences between respective means at $P \leq 0.05$ 
diameter $(P=0.007)$, stem height $(P<0.001)$, stem biomass $(P<0.001)$, leaf biomass $(P<0.001)$, below-ground biomass $(P=0.033)$, whole-plant fresh $(P<0.001)$, and dry mass $(P<0.001)$. Significant differences between fullsib families were also found for the concentrations of some leaf nutrients and for phytochemical traits $[\mathrm{Ca}(P<0.001)$, $\mathrm{N} \quad(P=0.004), \mathrm{Mg}(P=0.004), \mathrm{Mn}(P<0.001), \mathrm{P}$ $(P=0.002), \mathrm{K}(P=0.009)$, soluble phenolic compounds $(P=0.005)$, glucose $(P<0.001)$, fructose $(P=0.009)]$, whereas $\mathrm{C}, \mathrm{S}, \mathrm{Fe}$, starch, chlorophyll, carotenoids, and soluble protein $(P>0.05)$ were unaffected by genetic differences between the full-sib families. Fungicide treatment had no significant influence on morphometric or phytochemical parameters in aspen (Supplement 1).

To classify full-sib aspen families according to their morpho- and chemometric characteristics, principle component analysis of growth and phytochemical parameters was conducted. Three components were extracted that contributed $39.7 \%$ (component 1), $22 \%$ (component 2), and $21 \%$ (component 3 ) of the variability. The performance of $\mathrm{C} 1, \mathrm{C} 2$, and $\mathrm{C} 4$ was strongly influenced by shoot biomass and side shoots numbers and that of $\mathrm{C} 3, \mathrm{C} 5$ and $\mathrm{C} 7$ by relative growth and $\mathrm{Mn}$ concentrations (Component 1 , Fig. 2). Only C6 was strongly affected by component 2 that was mainly defined by bud break and soluble phenolics (Fig. 2).

Mantel tests were conducted to investigate relationships between genetic variance of the neutral markers and two parameter sets for tree performance, i.e., green leaf chemistry (mineral nutrients, phenolic compounds, carbohydrates, pigments, and protein) and tree morphology

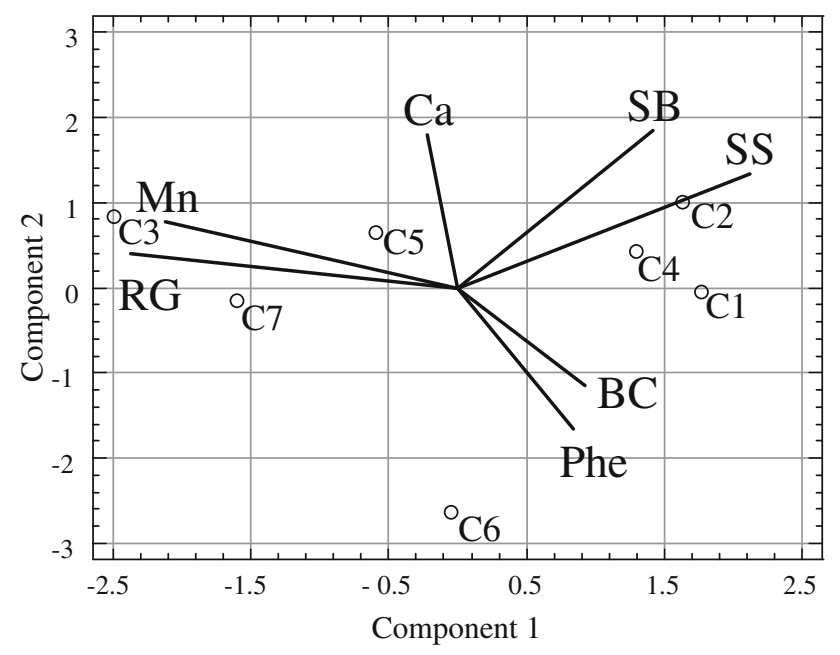

Fig. 2 Principal component analysis. The analysis was based on the following parameters: $S B$ stem biomass, $B C$ time until bud break was completed, $S S$ number of side shoots, $R G$ relative growth rate, and foliar concentrations of $\mathrm{Phe}=$ soluble phenolics, $\mathrm{Mn}$ manganese, $\mathrm{Ca}$ calcium
Table 1 Results of a Mantel test conducted for the relationship between genetic variance and tree performance

\begin{tabular}{ll}
\hline Parameter group & $P_{\text {(genetic variance) }}$ \\
\hline Green leaf chemistry & 0.3816 \\
Plant morphology & 0.9013 \\
All parameters & 0.8957 \\
\hline
\end{tabular}

* Genetic variances were calculated on the basis of the five neutral markers used to test the populations. Performance parameters were leaf chemistry (mineral nutrients, phenolic compounds, carbohydrates, pigments, and protein), tree morphology (biomass of leaves, stem, and roots; leaf area, stem height increment, stem diameter, leaf numbers, whole-plant leaf area, relative leaf water content, number of side shoots, cumulative length of side shoots), or all plant parameters analysed

(biomass of leaves, stem, and roots; leaf area, stem height increment, stem diameter, leaf numbers, whole-plant leaf area, relative leaf water content, number of side shoots, cumulative length of side shoots) (Table 1). However, neither leaf chemistry nor tree morphology showed significant relations with the genetic variance of the five neutral markers applied here. Furthermore, the neutral markers showed significantly higher molecular variance within a full-sib family than between families (among families: $D F=6$, variation $39 \%$; within families: $D F=$ 108, variation 69\%, PhiPT 0.3941, $P=0.010$ ).

To investigate whether plant traits differed more strongly between families without common parents than between those with a common parent, the trees were combined in a matrix showing 7 combinations for common fatherhood, 2 combinations for common motherhood, and 12 combinations without common parents (Supplement 2). The differences between tree traits were calculated for each combination and compared by ANOVA. Among 30 traits tested, 26\% (annual stem diameter increment, number of side shoots, fructose, protein, carbon, calcium, potassium, and manganese) showed significant differences according to parenthood (Table 2). However, only half of them (annual stem increment, number of side shoots, fructose, and protein) showed the expected stronger difference in progenies without common parents than in those with common parents and suggests a strong paternal influence on these parameters.

Performance of full-sib families in relation to growth and defense compounds

Since growth-related parameters and soluble phenolic concentrations showed significant differences between the full-sib families, the relationship between these features was further explored. We expected that high production of phenolic compounds would consume carbon and energy, which would, thus, be unavailable for biomass production 
Table 2 Differences in plant traits between different parenthoods

\begin{tabular}{|c|c|c|c|c|}
\hline \multirow[t]{2}{*}{ Parameter } & \multicolumn{3}{|l|}{ Differences* for } & \multirow[t]{2}{*}{$P$} \\
\hline & Common father & Common mother & No common parent & \\
\hline \multicolumn{5}{|l|}{ Annual stem } \\
\hline Increment $(\mathrm{mm})$ & $-0.06 \pm 0.27 \mathrm{a}$ & $0.30 \pm 0.37 \mathrm{ab}$ & $1.02 \pm 0.26 b$ & 0.042 \\
\hline Number of side shoots & $1.32 \pm 2.80 \mathrm{a}$ & $11.17 \pm 1.37 b$ & $8.97 \pm 1.71 b$ & 0.004 \\
\hline Fructose $\left(\mathrm{mg} \mathrm{g}^{-1} \mathrm{DM}\right)$ & $-0.09 \pm 0.03 \mathrm{a}$ & $0.25 \pm 0.09 b$ & $0.20 \pm 0.04 \mathrm{ab}$ & 0.001 \\
\hline Protein $\left(\mathrm{mg} \mathrm{g}^{-1} \mathrm{DM}\right)$ & $0.64 \pm 0.072 \mathrm{a}$ & $-2.87 \pm 1.02 b$ & $-1.27 \pm 0.57 b$ & 0.052 \\
\hline Carbon $(\%)$ & $-0.29 \pm 0.13 \mathrm{a}$ & $0.33 \pm 0.45 b$ & $0.09 \pm 0.08 \mathrm{~b}$ & 0.037 \\
\hline Calcium (mg g $\left.{ }^{-1} \mathrm{DM}\right)$ & $-2.15 \pm 0.50 \mathrm{a}$ & $-0.81 \pm 0.17 \mathrm{a}$ & $1.62 \pm 0.24 b$ & 0.001 \\
\hline Potassium (mg g $\left.{ }^{-1} \mathrm{DM}\right)$ & $-1.65 \pm 0.22 \mathrm{a}$ & $-1.12 \pm 0.15 \mathrm{ab}$ & $1.34 \pm 0.48 b$ & 0.001 \\
\hline Manganese $\left(\mathrm{mg} \mathrm{g}^{-1} \mathrm{DM}\right)$ & $-0.02 \pm 0.00 \mathrm{a}$ & $-0.01 \pm 0.00 \mathrm{a}$ & $0.01 \pm 0.00 \mathrm{~b}$ & 0.000 \\
\hline
\end{tabular}

of stem and root tissues. Instead of negative trade-off, we found that the total amount of phenolics in leaves was strictly positively correlated with total plant stem + root biomass (= non-green tissue, Fig. 3, open symbols). The same was true if the relationship between the amount of phenolics and stem biomass was considered $(R=0.911$, $P=0.004)$. We further argued that if there was a trade-off between the production of non-green tissue and phenolics in leaves, a negative relationship between the concentration of phenolics per unit of leaf tissue and the amount of nongreen tissue per green tissue must be expected. However, this was not observed (Fig. 3, closed symbols). Similarly, the concentration of phenolic compounds and the relative annual growth rate were unrelated $(R=0.449$, $P=0.311)$.

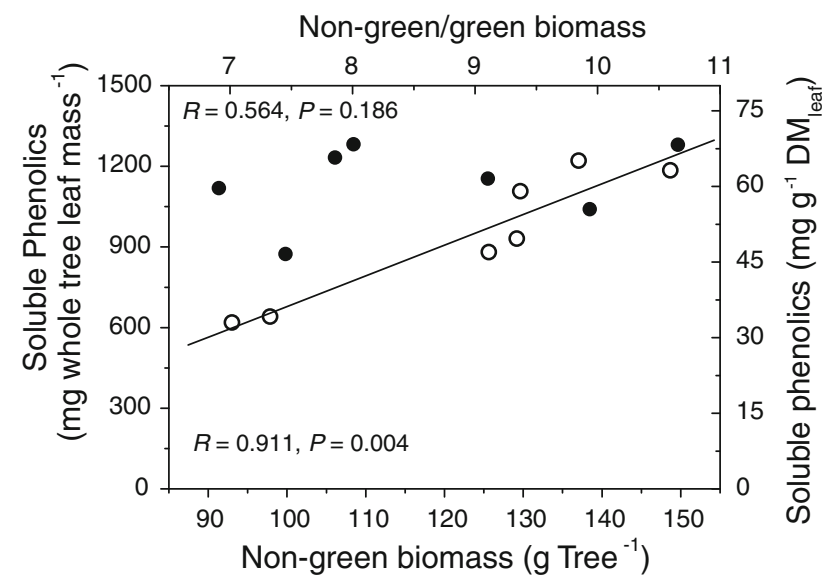

Fig. 3 Relationship between total amount of soluble phenolics in leaves and non-green (= stem + root) biomass (left and lower axis, black symbols) and between the concentration of soluble phenolics and the ratio of non-green tissue-to-green tissue (right and upper axis, white symbols)
Relationships of full-sib aspen families with interacting biota and influence of fungicide treatment

The roots of all full-sib families were colonized by arbuscular (27\%) and ectomycorrhizal fungi (16\%). Spearman correlation revealed a marginally significant negative correlation between the abundance of arbuscular and ectomycorrhizal fungi $(R=-0.741, P=0.056)$. Significant effects of full-sib families or of fungicide treatment on mycorrhizal abundance were not found (Supplement 1).

Endophyte colonization was only scored in two full-sib families, C3 and C4, respectively, which were characterized by a stark contrast in the concentrations of phenolic compounds (20.9 vs. $30.8 \mathrm{mg} \mathrm{g}^{-1}$ leaf fresh mass). Between these two families, no significant differences for endophyte colonization were detected (score of leaf colonization: $43 \pm 8 \%, P=0.948)$. However, treatment with the fungicide Amistar, which was applied by soil drench, resulted in a significant decrease in endophyte colonization of leaves of both families (Table 3). The effect was specific for this fungal lifestyle because mycorrhizal colonization was unaffected by the fungicide (Table 3, Supplement 1).

Table 3 Influence of fungicide treatment on endophytes and mycorrhizas

\begin{tabular}{lllr}
\hline & Control & Fungicide* $^{*}$ & $P$ \\
\hline Endophyte (\% of leaf pieces) & $65 \pm 6$ & $24 \pm 5$ & $<0.001$ \\
$\begin{array}{l}\text { Arbuscular mycorrhiza } \\
\quad \% \text { of root cells) }\end{array}$ & $25 \pm 3$ & $27 \pm 3$ & 0.634 \\
Ectomycorrhiza (\% of root tips) & $14 \pm 1$ & $18 \pm 1$ & 0.010 \\
\hline
\end{tabular}

* The fungicide Amistar $^{\odot}$ was applied once a month from April to August. Colonization by endophytic fungi was scored on leaf pieces, colonization by ecto- and arbuscular mycorrhizal fungi was scored on roots. Data show means $( \pm \mathrm{SE})$ for families $\mathrm{C} 3$ and $\mathrm{C} 4$ 


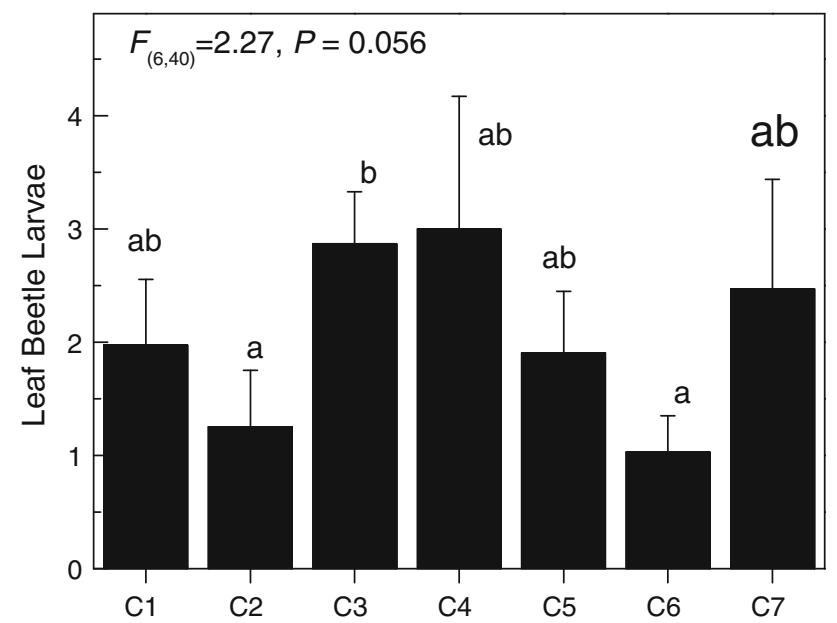

Fig. 4 Abundance of chrysomelid larvae on leaves of seven full-sib families of aspen ( $P$. tremula). Data indicate means $(n=24-28$, \pm SE). Different lower-case letters indicate significant pairwise differences between respective means at $P \leq 0.05$

The full-sib families also differed in herbivorous insect infestation, since leaf beetle larvae were significantly less abundant on leaves of the families $\mathrm{C} 2$ and $\mathrm{C} 6$ than on those of C3 (Fig. 4). There were no effects of different full-sib families on aphids and the sum of sucking insect abundance (Supplement 1). A linear mixed-effect model of foliar phenolics was significant for the abundance of leaf beetle larvae $\left(F_{(1,19)}=7.22, P=0.014\right)$ as well as for the sum of chewing insects (Fig. 5), whereas no significant effects were found for the abundance of aphids $\left(F_{(1,19)}=0.37, P=0.545\right)$ or the sum of sucking insects $\left(F_{(1,19)}=0.28, P=0.602\right)$.

\section{Discussion}

In this study, we included a large range of morphometric and chemometric measures for phenotyping of aspen. We found significant variation in these quantitative traits in the progenies of local parental trees but correspondence between variance for neutral molecular genetic markers and phenotypic characteristics was not found. This was not unexpected, since attempts to correlate genetic information based on neutral markers with traits of ecophysiological significance, e.g., timing of bud break, growth, or other quantitative traits have frequently been unsuccessful (McKay and Latta 2002; Bekessy et al. 2003). Similarly, meta-analysis revealed only a very weak correlation between quantitative traits and molecular measures for genetic variation (mainly isozyme-based analyses, Reed and Frankham 2001). A comparison of neutral markers, SNPs in candidate genes and quantitative phenological parameters such as bud break, bud set, seasonal increase in

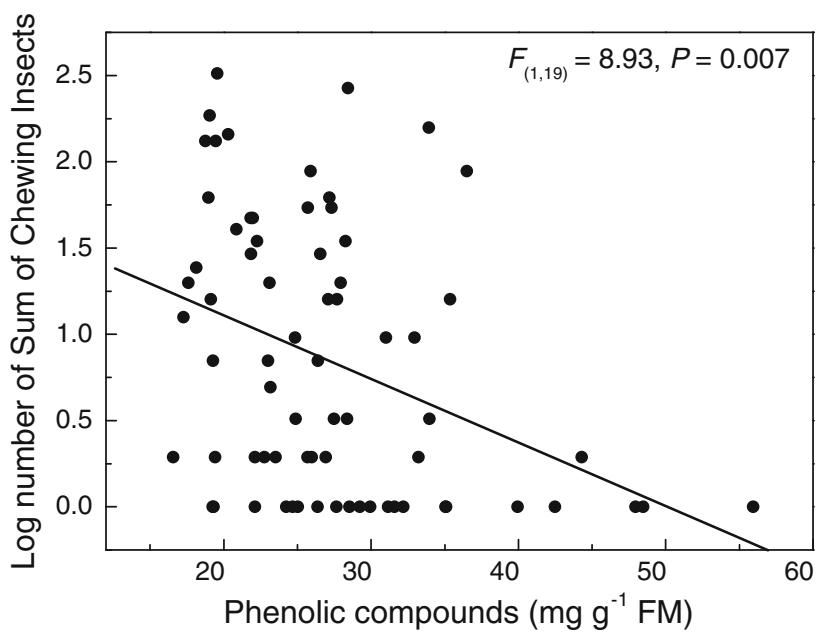

Fig. 5 Relationship between the concentration of soluble phenolics in leaves and the abundance of chewing insects (note log-scale)

tree height, and stem diameters in P. tremula genotypes from a clinal gradient also failed to detect significant correlations between molecular and phenological measures (Hall et al. 2007). In contrast to those studies, Madritch et al. (2009) found a significant correlation between genetic distance and green leaf chemistry for $P$. tremuloides clones. However, our data do not support such a relationship in $P$. tremula, probably because the genetic variance within a family of siblings was higher than between different families. Nevertheless, some morphological and phytochemical traits showed significant parental influence. The reason for this apparent contradiction is probably that genetic variance was measured with neutral markers, whereas phenotypic characteristics are the integrative result of many functional genes.

In $P$. tremula, the concentration of phenolics was under genetic control such as in $P$. tremuloides (Osier and Lindroth 2006; Donaldson and Lindroth 2007). Interestingly, allocation of a range of nutritional elements such as $\mathrm{N}, \mathrm{P}, \mathrm{Ca}, \mathrm{Mg}$, and $\mathrm{Mn}$ was also under genetic control in $P$. tremula. $\mathrm{N}$ and $\mathrm{P}$ are major compounds in biogeochemical cycles. The elements $\mathrm{Ca}$ and $\mathrm{Mg}$ are important in ecological nutrient cycles stabilizing or counteracting decreases in soil pH (Guckland et al. 2009). Litter input of fast-degrading leaves, therefore, has profound effects on ecosystem processes. Whether the observed differences in leaf quality and quantities would be sufficient to influence ecosystem functions, for example, in plantations remains to be seen. With respect to $\mathrm{Mn}$, genetic differences in uptake and root-to-shoot allocation have been reported for the interior and coastal race of Douglas fir (Ducic et al. 2006). The interior Douglas fir showed better performance on poor soils than the coastal provenience (Ducic et al. 2009), but in some locations, its inability to limit Mn translocation to above-ground plant tissues caused severe bark diseases 
resulting in significant economic loss (Schöne 1992). Our findings underline that it will be worthwhile to investigate the genetic basis of mineral nutrient allocation, especially if aspens were used for agroforestry systems.

Leaf concentrations of phenolic compounds are important factors shaping interactions with other biota (Orians et al. 1997; Glynn et al. 2004; Whitham et al. 2006). Their concentrations vary strongly between different Populus species and their hybrids, and these variations are inversely correlated with infestation with leaf galls and arthropods (Glynn et al. 2004; Whitham et al. 2006; Holeski et al. 2009). In greenhouse experiments with $P$. tremuloides, phenolic glycoside concentrations were the best predictor for gypsy moth larval performance (Donaldson et al. 2006; Donaldson and Lindroth 2007). Our data indicate that variation in leaf phenolics of $P$. tremula mediated interactions with leaf beetle larvae, belonging to the genus Phratora and Crepidodera. These chrysomelid species are generalists on salicaceous plants and not specifically adapted to the utilization of phenolic glucosides like some other Chrysomela species (Denno et al. 1990; Glynn et al. 2004; Ikonen 2002). High concentrations of leaf phenolic compounds provide a protection from generalist herbivores as indicated by the negative relationship between phenolics and leaf beetle larvae abundance. Our data further suggest that the costs incurred by this constitutive protection are too small to result in significant trade-off for growth or biomass production.

In this study, the influence of Amistar Opti, a strobilurin-based antifungal compound, was also studied. The active agent has initially been isolated from Strobilurus tenacelus, a saprophytic fungus growing on pine cones (Anke et al. 1977). Although this fungicide acts against a broad number of fungal species from different classes (ascomycota, basidiomycota, oomycetes), we showed that it does not suppress mycorrhiza formation. This has also been reported for other modern fungicides (Feldmann 2003; Watson 2006). Mycorrhizal colonization of aspens in our study was similar to that found in other field studies (Baum and Makeschin 2000). In fact, ectomycorrhizas even tended to be more abundant in fungicide-treated trees, which may be the result of reduced growth of potential competitors. Endophytic fungi, which colonize the apoplastic space of plant tissues and feed on plant carbohydrates, may be such competitors. They were strongly suppressed by Amistar Opti. Although endophytes often increase plant performance (Clay 1996; Morse et al. 2002; Bailey et al. 2005; but see Faeth and Sullivan 2003), we did not find negative effects of their suppression on plant nutrition, growth, or insect feeding in this short-term study. Since trees are cultivated for several years before harvest, it will be important for future investigations to assess whether the reduction in endophytes has long-term negative effects.

\section{Conclusions}

We showed that full-sib aspen families exhibit significant intraspecific variation in growth and ecophysiological leaf traits and that some of these traits are clearly related to parenthood. In contrast to our expectation, production of phenolic compounds, which act as defense against generalist herbivores, did not show negative trade-off with growth. Probably, the concentrations of these compounds were too low compared with lignin production or other energy-consuming processes to influence growth behavior. Application of a systemic fungicide neither suppressed mycorrhizal colonization nor affected infestation with insects. However, a strong suppression of endophytes was found, whose long-term consequences may require attention when fungicides are used in agroforestry plantations.

Acknowledgments We are grateful to G. Langer-Kettner, C. Kettner, M. Smiatacz for their help with the installation of the common garden experiment and plant harvest and to M. Franke-Klein for her help with the photometric assays. We thank the Niedersächsisches Ministerium für Wissenschaft und Kultur and the "Niedersächsisches Vorab" for funding "Functional Ecology Research". The authors declare that they have no conflict of interest.

Open Access This article is distributed under the terms of the Creative Commons Attribution Noncommercial License which permits any noncommercial use, distribution, and reproduction in any medium, provided the original author(s) and source are credited.

\section{References}

Anke T, Oberwinkler F, Steglich W, Schramm G (1977) The strobilurins-new antifungal antibiotics from the basidiomycete Strobilurus tenacellus (PERS. Ex FR.). J Antibiot 30:806-810

Bailey JK, Deckert R, Schweitzer JA, Rehill BJ, Lindroth RL, Gehring C, Whitham T (2005) Host plant genetics affect hidden ecological players: links among Populus, condensed tannins, and fungal endophyte infection. Can J Bot 83:356-361

Baum C, Makeschin F (2000) Effects of nitrogen and phosphorus fertilization on mycorrhizal formation of two poplar clones (Populus trichocarpa and P. tremula $\mathrm{x}$ tremuloides). J Plant Nutr Soil Sci 163:491-497

Bekessy SA, Ennos RA, Burgman MA, Newton AC, Ades PK (2003) Neutral DNA markers fail to detect genetic divergence in an ecologically important trait. Biol Conserv 110:267-275

Burnham KP, Anderson DR (2002) Model selection and multimodel interference. A practical information-theoretic approach. Springer, New York

Clay K (1996) Interactions among fungal endophytes, grasses and herbivores. Res Popul Ecol 38:191-201

Crawley MJ (2007) The R book. Wiley, New York

Dayanandan S, Rajora OP, Bawa KS (1998) Isolation and characterization of microsatellites in trembling aspen (Populus tremuloides). Theor Appl Genet 96:950-956

DeChantal M, Lindberg H, Kallonen S (2009) The condition of Populus tremula and other deciduous saplings in a moose winter foraging area in southern Finland. Ann Bot Fennici 46:280-290 
Denno RF, Larsson S, Olmstead KL (1990) Role of enemy-free space and plant quality in host-plant selection by willow beetles. Ecology 71:124-137

Dickmann DI, Kuzovkina J (2008) Poplars and willows of the world, with emphasis on silviculturally important species. Rome, Italy: FAO Forest Management Division Working Paper IPC/9-2, 129 $\mathrm{p}$

Dimpfelmeier R (1963) Ergebnisse fünfjähriger Kombinationszüchtungsversuche mit Populus tremula L. Forstwiss Centralbl 82:295-304

Donaldson JR, Lindroth RL (2007) Genetics, environment, and their interaction determine efficacy of chemical defense in trembling aspen. Ecology 88:729-739

Donaldson JR, Kruger EL, Lindroth RL (2006) Competition- and resource-mediated tradeoffs between growth and defensive chemistry in trembling aspen (Populus tremuloides). New Phytol 169:561-570

Dučić T, Leinemann L, Finkeldey R, Polle A (2006) Uptake and translocation of manganese in seedlings of two races of Douglas fir (Pseudotsuga menziesii var. viridis and glauca). New Phytol 170:11-20

Dučić T, Berthold D, Langenfeld-Heyser R, Beese F, Polle A (2009) Mycorrhizal communities in relation to biomass production and nutrient use efficiency in two varieties of Douglas fir (Pseudotsuga menziesii var. menziesii and var. glauca) in different forest soils. Soil Biol Biochem 41:742-753

Faeth S, Sullivan T (2003) Mutualistic asexual endophytes in a native grass are usually parasitic. Am Nat 161:310-325

Feldmann F (2003) Nebenwirkungen von Pflanzenschutzmitteln auf arbuskuläre Mykorrhizapilze als Nichtzielorganismen, Fachtagung, 4.11.2003, BBA Braunschweig

Glynn C, Rönnberg-Wästljung A-C, Julkunen-Tiitto R, Weih M (2004) Willow genotype, but not drought treatment, affects foliar phenolic conentrations and leaf beetle resistance. Entomol Exp Appl 113:1-14

Guckland A, Jacob M, Flessa H, Thomas FM, Leuschner C (2009) Acidity, nutrient stocks, and organic-matter content in soils of a temperate deciduous forest with different abundance of European beech (Fagus sylvatica L.). J Plant Nutr Soil Sci 172:500-511

Hall D, Luquez V, Garcia VM, St Onge KR, Jansson S, Ingvarsson PK (2007) Adaptive population differentiation in phenology across latitudinal gradient in European aspen (Populus tremula L.): a comparison of neutral markers, candidate genes and phenotypic traits. Evolution 61:2849-2860

Heinrichs H, Brumsack HJ, Loftfield N, Konig N (1986) Improved pressure digestion system for biological and anorganic materials. Z Pflanzenernähr Bodenkd 149:350-353

Holeski LM, Vogelzang A, Stanosz G, Lindroth RL (2009) Incidence of Venturia shoot blight in aspen (Populus tremuloides Michx.) varies with tree chemistry and genotype. Biochem Syst Ecol 37:139-145

Hsu JC (1996) Multiple comparisons: theory and methods. Chapman and Hall, London

Hultén E, Fries M (1986) Atlas of North European vascular plants, north of the tropic of cancer. Konigstein V(1-3):1172

Ikonen A (2002) Preferences of six leaf beetle species among qualitatively different leaf age classes of three Salicaceous host species. Chemoecology 12:23-28

Kendall DA, Hunter T, Arnold GM, Liggit J, Morris T, Wiltshire CW (1996) Susceptibility of willow clones (Salix spp.) to herbivory by Phyllodecta vulgatissima (L.) and Galerucella lineola (Fab.) (Coleoptera, Chrysomelidae). Ann Appl Biol 129:379-390

Kouki J, Arnold K, Martikainen P (2004) Long-term persistence of aspen-a key host for many threatened species-is endangered in old-growth conservation areas in Finland. J Nat Conserv $12: 41-52$

Li B, Wu R (1997) Heterosis and genotype x environment interactions of juvenile aspens in two contrasting sites. Can J For Res 27:1525-1537

Lichtenthaler HK, Wellenburn AR (1983) Determinations of total carotenoids and chlorophylls $\mathrm{a}$ and $\mathrm{b}$ of leaf extracts in different solvents. Biochem Soc Trans 11:591-592

Liesebach M, von Wuehlisch G, Muhs H-J (1999) Aspen for shortrotation coppice plantations on agricultural sites in Germany: effects of spacing and rotation time on growth and biomass production of aspen progenies. For Ecol Manag 121:25-39

Luo ZB, Calfapietra C, Libberloo M, Scarascia-Mugnozza G, Polle A (2006) Carbon partitioning to mobile and structural fractions in poplar wood under elevated $\mathrm{CO}_{2}$ (EUROFACE) and $\mathrm{N}$ fertilization. Glob Change Biol 12:272-283

Luo ZB, Calfapietra C, Scarascia-Mugnozza G, Liberloo M, Polle A (2008) Carbon-based secondary metabolites and internal nitrogen pools in Populus nigra under free air $\mathrm{CO}_{2}$ enrichment (FACE) and nitrogen fertilisation. Plant Soil 304:45-57

Madritch MD, Greene SL, Lindroth RL (2009) Genetic mosaics of ecosystem functioning across aspen-dominated landscapes. Oecologia 160:119-127

McKay JK, Latta RG (2002) Adaptive population divergence: markers, QTL and traits. Trends Ecol Evol 17:285-291

Morse LJ, Day TA, Faeth SH (2002) Effect of Neotyphodium endophyte infection on growth and leaf gas exchange of Arizona fescue under contrasting water availability regimes. Environ Exp Bot 48:257-268

Orians CM, Huang CH, Wild A, Dorfman KA, Zee P, Dao MTT, Fritz RS (1997) Willow hybridization differentially affects preference and performance of herbivorous beetles. Entomol Exp Appl $83: 285-294$

Osier TL, Lindroth RL (2006) Genotype and environment determine allocation to and costs of resistance in quaking aspen. Oecologia 148:293-303

Pasteels JM, Rowell-Rahier M, Braekman JC, Dupont A (1983) Salicin from host plant as precursor of salicylaldehyde in defensive secretion of chrysomeline larvae. Physiol Entomol 8:307-314

Peakall R, Smouse PE (2001) GENALEX V5.04: genetic analysis in EXCEL. Population Genetic Software for Teaching and Research. Australian National University,Canberra, Australia, available at http://www.anm.edu.au/ BoZo/GcnAlEX/

Petrini O (1986) Taxonomy of endophytic fungi of aerial plant tissues. In: Fokkema NJ, van den Heuvel J (eds) Microbiology of the Phyllosphere. Cambridge University Press, Cambridge, pp $175-187$

Pinheiro JC, Bates DM (2000) Mixed-effects models in S and S-PLUS. Springer, New York

Rahman MH, Dayanandan S, Rajora OP (2000) Microsatellite DNA markers in Populus tremuloides. Genome 43:293-297

R Development Core Team (2007) R: a language and environment for statistical computing. R foundation for statistical computing. Vienna, Austria, http://www.R-project.org

Reed DH, Frankham R (2001) How closely correlated are molecular and quantitative measures of genetic variation? A meta-analysis. Evolution 55:1095-1103

Rowell-Rahier M (1984) The presence or absence of phenolglycosides in Salix (Salicaceae) leaves and the level of dietary specialisation of some of their herbivorous insects. Oecologia 62:26-30

Sambrook J, Fritsch EF, Maniatis T (1989) Molecular cloning: a laboratory manual, 2nd edn. Cold Spring Harbor Laboratory Press, Plainview, New York 
Schöne D (1992) Site-rain and acid-rain induced nutritional disorders of Douglas-fir in Southwestern Germany. Allg Forst Jagdztg 163:53-59

Schopfer P (1989) Experimentelle Pflanzenphysiologie, Band 2, Einführung in die Anwendung. Springer, Berlin, Heidelberg, New York, pp 39-50

Tamm Ü (2006) Populus tremula, in Enzyklopädie der Laubbäume. Nikolai, Hamburg, pp 405-414

UPOV (1981) Guidelines for the conduct of tests for distinctness, homogeneity and stability: poplar (Populus L.), UPOV, TG 21/7, pp. 20

Van Der Schoot M, Pospiškova M, Vosman B, Smulders MJM (2000) Development and characterization of microsatellite markers in black poplar (Populus nigra L.). Theor Appl Genet 101:317-322
Venables WN, Ripley BD (2002) Modern applied statistics with S, 4 th edn. Springer, New York

Watson GW (2006) The effect of paclobutrazol treatment on starch content, mycorrhizal colonization, and fine root density of white oaks (Quercus alba L.). Arboricult Urb For 32:114-117

Whitham TG, Bailey JK, Schweitzer JA, Shuster SM, Bangert RK, LeRoy CJ, Lonsdorf E, Allan GJ, DiFazio SP, Potts BM, Fischer DG, Gehring CA, Lindroth RL, Marks J, Hart SC, Wimp GM, Wooley SC (2006) A framework for community and ecosystem genetics: from genes to ecosystems. Nat Rev Gen 7:510-523 